\title{
The Use of Paint Waste as A Raw Material of Paving Block
}

\author{
Ari Dina Permana-Citra $\left.{ }^{*}, 1\right)$, Purwanto Purwanto ${ }^{1,2), ~ H e n n a ~ R y a ~ S o e n o k o ~}{ }^{1,3}$ \\ ${ }^{1)}$ Doctorate Program of Environmental Science, School of Postgraduate Studies, Universitas Diponegoro, Semarang Indonesia \\ ${ }^{2)}$ Department of Chemical Engineering, Faculty of Engineering, Universitas Diponegoro, Semarang Indonesia \\ ${ }^{3)}$ Study Program of Pharmacy, Faculty of Medical, Universitas Diponegoro, Semarang Indonesia
}

\begin{abstract}
The beauty packaging industry uses paints for colouring to attract the consumers. The generation of hazardous paint waste need to be well managed to minimize negative impact on the environment. This research is intended to investigate the utilization of paint waste as a raw material of paving block. The variations of waste addition are used to study the compressive strength of paving based on the mixture of sand and cement. The addition of paint waste by $2.5 \% \mathrm{w} / \mathrm{w}$ diminishes the compressive strength from 25.6 MPa to $9.9 \mathrm{MPa}$. The compressive strength for the addition of $5 \%, 7.5 \%, 10 \%$, and $15 \%$ are $7.8,3.1$, 3.2 and 2.2 respectively. The reduction of compressive strength due to the addition of paint waste indicate that the direct utilisation for production of paving block is not viable. Water absorption test value not meet the specifications of paving block SNI 03-0691-1996 which range from 1.67\%-11.38\%. The pre treatment of waste such as drying and grinding to eliminate the solvent is indispensible.
\end{abstract}

Keywords: Paint waste, waste to product, paving block

\section{Introduction}

Hazardous substance has became an important issue for its potential to generate negative impact for environment and human health. Data of Indonesian Ministry of Environmental and Forestry (MEF) 2017 shows that annually, manufacture industries generate hazardous waste at $1,079.05$ ton, which 937.94 ton has been processed. The remaining 141.11 ton, which is not yet properly processed, came from 28 manufacture companies (importer, producer, textile, pain, glass, and paper), which companies had became subject of supervising from January to September 2016. [1].

The government continuously encourage the business to carry out hazardous waste management through application of 3R (Reduce, Reuse, and Recycle). As well as one mandated on Government Regulation No 101 year 2014 about Management of Hazardous and Toxic Waste, each hazardous waste generate must apply waste management properly such as reduction, storage, collection, transportation, utilization, processing and/or handling. [2]

Packaging beauty industry is manufacture industry which generate hazardous waste from left over of decoration for coating plastic surface by using paint. It is in the form of mud. It is burn easily, corrosive, and toxic. The paint used is hazardous which is included in mixed hazardous for it is composed from several single hazardous ingredient. One of packaging industry generate waste at 12 ton annually. Its current processing is outsourced to third party for there hasn't been any suitable paint sludge processing technology yet. One alternative to utilize this hazardous waste is to convert waste into paving block. Paint sludge can be used as substitute raw material or additional material which is safe for health and environment and meet the quality standard. [3]

Paving block is a composition of building material which is made from Portland cement mixture or similar hydraulic adhesive, water and aggregate, with or without any additional material. Paving must have at least $60 \mathrm{~mm}$ thickness, with $\pm 8 \%$ tolerance. Compressive strength and water absorption are some parameter that should be pay attention to in order to maintain quality. Paving's compressive strength is highly influenced by ratio of its ingredient such as cement, sand, and additional aggregate. [3]

Previous research using fly ash as additional material on concrete at $20 \%$ and increase compressive strength until $16.198 \%$. This research utilized hazardous waste such as paint sludge on paving block as additional material, with several additional paint sludge variation will be measured on its effect against compressive strength and water absorption paving block.[4]

\footnotetext{
${ }^{*}$ Corresponding author: dinacitra@gmail.com
} 


\section{MATERIAL AND METHODS}

This research used test item in the form of Holland type paving block with its volume ratio and paint sludge addition at various concentration on $2.5 \%, 5 \%, 7.5 \%$, $10 \%$, and $15 \%$ of sand volume. The total mixture used is $31 \mathrm{~kg}$ at ratio of cement : sand equal 1:4.

Test item used is Paving Block type Holland on 20 $\mathrm{cm} \times 10.5 \mathrm{~cm}$. The process of this test item used press machine, with each mold contain 10 paving blocks. The process started with ingredient mixing then put into the mold. The mold is vibrated in order to fill the cavities inside the mixture. The mold is then pressed by hydraulic system in order to make them more solid. After the molding process they are isolated from sunlight and watered every morning for two days before they are dried in the sun for 35 days.

Classification for paving block based on Indonesian National Standard (SNI) 03-0691-1996 are as follows:

1. A quality paving blocks are for road. Compressive strength at 35-49 $\mathrm{MPa}$.

2. B quality Paving blocks are for parking equipment, compressive strength 17-20 $\mathrm{MPa}$.

3. C quality paving blocks are for pedestrian, compressive strength 12.5-15 $\mathrm{MPa}$.

4. D quality paving blocks are fro park and such, compressive strength 8.5-10 $\mathrm{MPa}$.

Table 1. Mixing ration of raw materials for paving block.

\begin{tabular}{|c|c|c|c|c|c|}
\hline No & $\begin{array}{c}\text { \% Paint } \\
\text { Sludge }\end{array}$ & $\begin{array}{c}\text { Paint } \\
\text { Sludge } \\
(\mathrm{Kg})\end{array}$ & $\begin{array}{c}\text { Cement } \\
(\mathrm{Kg})\end{array}$ & $\begin{array}{c}\text { Sand } \\
(\mathrm{Kg})\end{array}$ & Quantity \\
\hline 1 & 0 & 0 & 6 & 24 & 3 \\
\hline 2 & 2,5 & 0.75 & 6 & 23.25 & 3 \\
\hline 3 & $5 \%$ & 1.5 & 6 & 22.5 & 3 \\
\hline 4 & $10 \%$ & 3 & 6 & 21 & 3 \\
\hline 5 & $15 \%$ & 4.5 & 6 & 19.5 & 3 \\
\hline
\end{tabular}

The test conducted is compressive strength and water absorption test on each Holland type paving block which use Compression Testing machine on 35 age days. The analysis result is expected to have relation between compressive strength and paint sludge addition on each concentrate.

Water absorption test is meant to see how much paving block can absorb water. The test is done on 3 test item on each variation at $2.5 \%, 5 \%, 7.5 \%, 10 \%$, and $15 \%$ compared to paving block without any paint sludge addition. Those test item are firstly weighted dry and then drown into water for 24 hours. They are then lift up and weighted wet. They are then dried on drying kitchen for 24 hour, at $105^{\circ} \mathrm{C}$ until their weight on two weighting have no more than $0,2 \%$ from the first previous weighing. This testing was conducted at Laboratory of Material and Building Department of Civil Engineering Faculty of Engineering, Universitas Diponegoro.

\section{Results and Discussion}

3.1 Paving Block Production

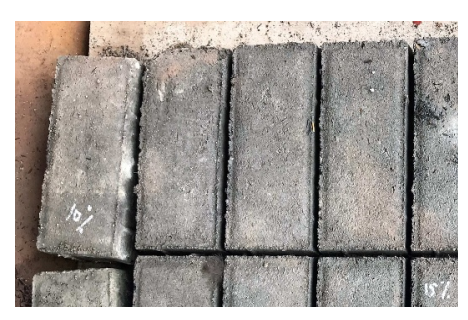

Figure 1. Paving Block with paint sludge variation $(0 \%$, $2.5 \%, \quad 5 \%, \quad 7.5 \%$, $10 \%, 15 \%)$

\section{Addition of} paint sludge by various

concentration cause change of colors of paving texture from light grey into dark grey. Color is not a requirement in SNI 03-0681-1996. The requirement of quality that must be met is flat surface, no crack and flaw, the corner parts are not easily trimmed by hand and minimum thickness is $60 \mathrm{~mm}$ with $\pm 8 \%$ tolerance.

\subsection{Result of Compressive Strength Test}

Compressive strength test on paving block with additional paint sludge at various concentrate: $2.5 \%, 5 \%$, $7.5 \%, 10 \%$, and $15 \%$ of sand volume is shown on Figure 2.

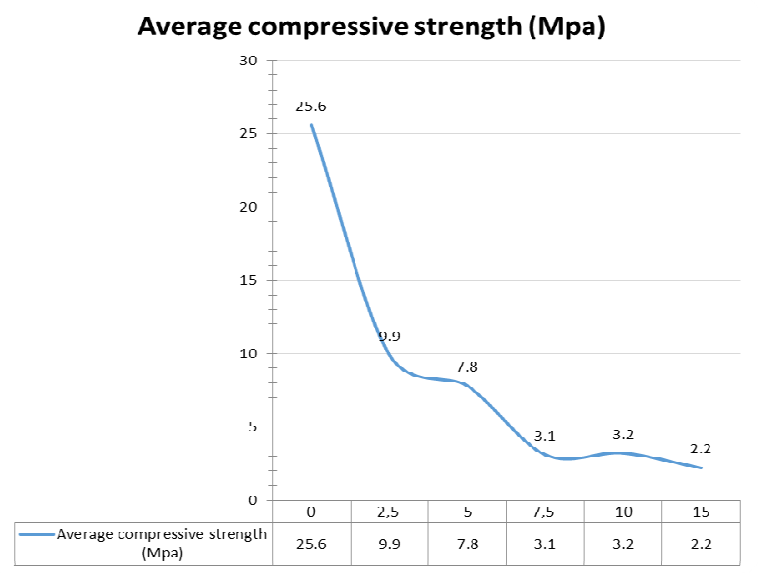

Figure 2. Compressive strength as paint sludge addition

Figure 2 shows that average compressive strength value on paving block experience a decrease in line with exponential addition of paint sludge concentration. The addition of paint sludge as substitute main ingredient of sand make the mixture cannot come together well enough because of existing solvent which is insoluble on water. Paving at $15 \%$ of paint sludge has expanding physical form that cause forming of cavities making the significant reduction of compressive strength.

The making process of paving block is done by density of mixture in order that every mixed ingredient become solid, making the pores volume are lessen. 
High volume of water will cause a lot of water bubble after the hydration process had done. On the contrary, too low volume of water will cause fail hydration process which effect the paving strength. It happens to paving with $15 \%$ addition of paint sludge.

The result of compressing strength on paving block with variety of paint sludge mixing on 2.2 MPa-25.7 $\mathrm{MPa}$, on paint sludge addition at $2.5 \%$ on paving block meet the requirement of $\mathrm{D}$ quality which can be used on park and other facilities according to SNI 03-0691-1996.

On previous research, the addition of rubber waste on road construction on variety of mixing at $10 \%, 20 \%$, $30 \%$, and $40 \%$ with particle size at $4.04 \mathrm{~mm}$ experienced reduction of compressive strength which is caused by weak bonds between rubber and paving [5].

Saiki and de Brito (2012) stated that the addition of rubber waste as substitute of sand on paving decrease its compressive strength and water absorption to any paving mixed with polyethylene terephthalate (PET) waste. [6].

In Belgium, secondary aggregate utilization is applied in order to emphasize and to focus more on environment and health issues. Sudarno et al. (2014) did research on new road solidify layer, utilize recycle on old road solidify layer, which activities is economically conduct saving to $70.07 \%$ and meet the road compressive strength. [7] [8]

Gencel et al. (2012) did research to change some aggregate with marble waste on paving block. Physical and mechanical test are done on paving and resulted on decrement of compressive strength on reversal of increment of marble volume, mixing of marble waste generate good quality paving block [9].

\subsection{Test Result of Water Absorption}

The results of test was presented on Figure 3.

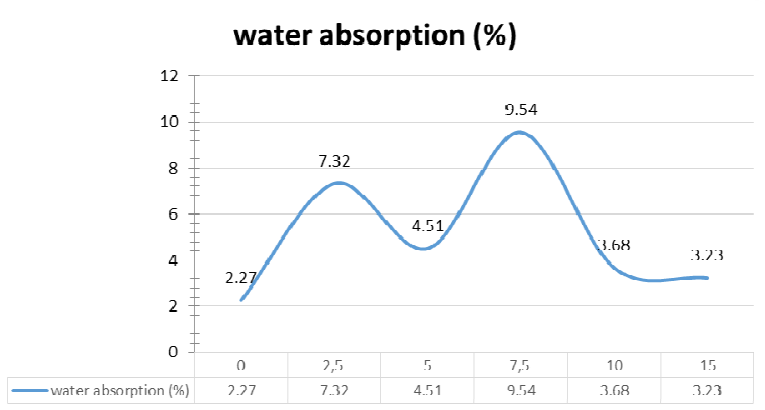

Figure 3. Water permeation average as paint sludge addition function.

Water absorption value is achieved from paving block wet weight minus paving block dry weight multiply $100 \%$. In order to met the A grade (for road), the average water absorption is $3 \%, \mathrm{~B}$ quality (parkir equipment) average water absorption $6 \%$, $\mathrm{C}$ quality (pedestrian) water absorption $8 \%$ and $\mathrm{D}$ quality (park and other use) average water absorption $10 \%$.

Water absorption of paving block on paint sludge addition of $2.5 \%$ meet the $\mathrm{C}$ quality, Water absorption of paving block on paint sludge addition of $5 \%$ meet the $\mathrm{B}$ quality, Water absorption of paving block on paint sludge addition of $7.5 \%$ meet the $\mathrm{D}$ quality, Water absorption of paving block on paint sludge addition of 15\% meet the B quality based on SNI 03-0691-1996 for paving block

Silva et al (2013) did some research of concrete mixing with plastic waste on variety of $0 \%, 7.5 \%$, and $15 \%$ from PET plastic waste which result showed high water absorption at $11.1 \%$ and $28.3 \%$. [4]

Mixed water and cement as test item will shrunk if dried and will expand if wet. The shrinkage will happens on initial age until they reach 7 days. When the test item expanded, the paving block hair crack will be visible and by using glass recycle can decrease volume of cement by $30 \%$ and did not effect compressive strength, durability against weather, and solidity. [10]

\section{Conclusions}

Paving Block without paint sludge or $0 \%$ concentration has gray color, whereas paving block with concentration varies from $2.5 \%$ to $15 \%$ change color to dark. The highest compressive strength value is resulted from paving block with $2.5 \%$ addition paint sludge volume at $9.9 \mathrm{MPa}$ is closest to D class. Based on SNI 03-0691-1996, compressive strength value, water absorption value of paving block at $2.5 \%-15 \%$ paint sludge mixing volume that met each quality for paving based on SNI 03-0691-1996.

\section{References}

1. MEF (Ministry of Environment and Forestry).2018. http://ppid.menlhk.go.id/siaran_pers/browse/1169.

2. Indonesia Government Regulation. 2014. PP No 101/2014. Management of Hazardous Waste.

3. SNI 03-0691-1996. Indonesian National Standard 03-0691-1996 for Paving Block

4. Silva, R.V., de Brito, J., Saika, N., 2013. Influence of Curing Conditions on The Durability-Related Performance of Concrete Made With Selected Plastic Waste Aggregates. Cement and Concerete Composite. Vol. 35. p.23-31.

5. Li, Li-Juan., Tu, Gui-Rong., Lan, Cheng., Liu, Feng. 2016. Mechanical characterization of waste-rubbermodified recycled-aggregate concrete. Journal of Cleaner Production. Vol. 124. p.325-338

6. Saiki, N. and de Brito, J .2012. Use of plastic waste as aggregate in cement mortar and concrete preparation: A review. Construction and Building Material. Vol. 34. p. 385-401.

7. Desmyter, J., Laethem, B., Simons, B., Van Dessel, J., Vyncke, J.. 1994. Towards Sustainability with Construction and Demolition Waste in Belgium? Studies in Environmental Science. Vol. 60. p. 759773.

8. Sudarno, S., Purwanto, P., and Praktikso, P., 2014. Life Cycle Assessment on Cement Treated 
Recycling Base (CTRB) Construction. Waste Technology (WasTech). Vol. 2. No 2. p.31-40.

9. Gencel, O., Ozel, C., Koksal, F., Erdogmus, E., Martinez-Barera, G., Brostow. W. 2012. Properties of concrete paving blocks made with waste marble. Journal of Cleaner Production. Vol. 21. p. 62-70.

10. Ganjian. E., Jalul. G., Pouya. S.H. 2015.Using waste materials and by-products to produce concrete paving blocks. Construction and Building Material. Vol. 77. p. 270-275. 